Agrovoc descriptors: vitis vinifera; grapevines; rootstocks; cuttings; grafting; transpiration; water; leaf area; roots; stems; daylight

Agris category code: F61,F62

COBISS code 1.01

\title{
Transpiration of the 'Rebula' cuttings (Vitis vinifera L.) grafted on three different rootstocks (Vitis sp.)
}

\author{
Primož LAVRENČIČ ${ }^{1}$, Paolo SIVILOTTI ${ }^{2,3}$, Enrico PETERLUNGER ${ }^{3}$
}

Received October 18, 2005; accepted August 11, 2006

Delo je prispelo 18. avgusta 2005; sprejeto 11. avgusta 2006

\begin{abstract}
The purpose of the investigation was to determine the use of water in grafted vines (Vitis vinifera L.) in dependence on the vine (Vitis sp.) rootstocks. The local vine variety 'Rebula' was grafted on three different rootstocks (Vitis sp.): (1) on the 'Rebula' (Vitis vinifera L.) vine itself, (2) on the rootstock 196/17 Castel' [(Vitis vinifera 'Mourvèdre' x Vitis rupestris '1202 Couderc') x Vitis riparia 'Gloire'] and (3) on the rootstock 'Börner' (Vitis riparia x Vitis cinerea). Daily transpiration was calculated as a difference in the pot mass between the day of measurement and the previous day. Daily differences in the use of water were compared with leaf area and meteorological data (temperature, duration of sun light). Stem water potential (SWP) and, at the end of the trial, leaf area and mass of individual parts of plant (roots, shoot) were determined using destructive method. The dynamics of water used per leaf area unit showed the trend of reduction and the response to the changing meteorological conditions. No statistically significant differences in SWP, leaf area and water used were noticed between rootstocks, however, they existed in the final mass of shoot and roots.
\end{abstract}

Key words: grapevine, cuttings, transpiration, rootstock

\section{IZVLEČEK}

\section{TRANSPIRACIJA CEPLJENK VINSKE TRTE (Vitis vinifera L.) 'REBULA' CEPLJENE NA TRI RAZLIČNE PODLAGE (Vitis sp.)}

Namen raziskave je bil določiti porabo vode pri enoletnih cepljenkah vinske trte (Vitis vinifera L.) v odvisnosti od podlage vinske trte (Vitis sp.). Lokalno vinsko sorto 'Rebula' smo cepili na tri različne podlage: (1) na samo sebe, 'Rebula' (Vitis vinifera L.), (2) podlago '196/17 Castel' [(Vitis vinifera 'Mourvèdre' $x$ Vitis rupestris '1202 Couderc') $x$ Vitis riparia 'Gloire'] in (3) podlago 'Börner' (Vitis riparia $x$ Vitis cinerea). Dnevna transpiracija je bila izračunana kot razlika $v$ masi lonca $z$ rastlino, med dnevom merjenja in predhodnim dnevom. Dnevne razlike $\checkmark$ porabi vode smo primerjali $z$ listno površino in meteorološkimi podatki (temperatura, sončno obsevanje). Določili smo vodni potencial stebla (SWP), na koncu poskusa pa, z destruktivno metodo, listno površino in maso posameznih delov rastlin (korenine, poganjek). Dinamika

1 Agricultural Institute of Slovenia, Hacquetova 17, SI-1000 Ljubljana, univ. dipl. ing. agr.

2 C.R.A. Experimental Institute for Viticulture, v.le. XXVIII Aprile 26, IT-31015 Conegliano (TV), Ph. D.

3 University of Udine, Department of Crop Science and Agricultural Engineering, Via delle Scienze 208, IT-33100 Udine, Associate Prof., Ph. D. 
porabe vode na enoto listne površine je pokazala odziv na spremenljive meteorološke razmere in trend zniževanja. Med podlagami nismo opazili statistično značilnih razlik $v$ vodnem potencialu stebla, listni površini in porabi vode, statistično značilne razlike med podlagami so obstajale le $v$ končni masi poganjka in korenin.

Ključne besede: vinska trte, cepljenke, transpiracija, podlage

\section{INTRODUCTION}

The water use of grapevines has been reported in the literature, either for mature vines (Gómez-del-Campo et al., 1997; Trambouze and Woltz, 2001) or young plants (Myburgh et al., 1996; Williams et al., 2003). As to the water requirement of 1-yearold grapevine cuttings there is a lack of knowledge, but this information may be useful in nurseries to optimise water. Furthermore, when an experimental plot with grapevine cuttings has to be set up, accurate irrigation planning is necessary for optimal cultivation.

The aim of this research was to estimate the amount of transpiration in relation with leaf area development in young grafted grapevines. At the same time, the influence of different rootstocks on this parameter was investigated, because rootstocks may affect vigour, water relations, mineral nutrition, yield and quality (Padget-Johnson et al., 2000).

\section{MATERIAL AND METHODS}

The old local grapevine variety 'Rebula' (Vitis vinifera L.), synonym 'Ribolla gialla', was grafted to: (1) itself, i.e. grafted to 'Rebula' (Vitis vinifera L.), (2) rootstock '196/17 Castel' [(Vitis vinifera 'Mourvèdre' $x$ Vitis rupestris '1202 Couderc') x Vitis riparia 'Gloire'] and (3) rootstock 'Börner' (Vitis riparia $x$ Vitis cinerea). Each grafting combination was represented by three replicates (plants). During January 2002 the grafting was performed using omega graft technique, and grafts were planted in a mist bench for two months in order to have a good rooting and growth. On $9^{\text {th }}$ of April 2002 the plants were transferred in 2 I pots filled with Agriperlite BPB Vic and Goldhumus Pflanzerde $(3 / 1, \mathrm{v} / \mathrm{v})$, and they were grown in a greenhouse at the "Antonio Servadei" experimental farm of the University of Udine, NorthEastern Italy. Evaporation from the substrate surface of the pot was avoided covering the top with aluminium foil. Percolation was negligible. The daily transpiration rate was calculated as pot weight difference between two following days. Daily differences of pot were related to the leaf area, to obtain the daily transpiration per unit of leaf area $\left(T_{a}\right)$.

At the beginning of this trial, the amount of water supplied was $0.15 \mathrm{I} \mathrm{pot}^{-1} \mathrm{~d}^{-1}$ : this level was established based on xylem-sap flow values in mature grapevines $(3-4) \mathrm{H}_{2} \mathrm{O} \mathrm{m}$ leaf area $\mathrm{d}^{-1}$; Sivilotti et al, 2005), and considering the initial leaf area per plant of about $0.05 \mathrm{~m}^{2}$. Because of rapid leaf area growth, water supply was increased up to $0.201 \operatorname{pot}^{-1} \mathrm{~d}^{-1}\left(1^{\text {st }}\right.$ of June 2002) and to $0.30 \mathrm{I} \mathrm{pot}^{-1} \mathrm{~d}^{-1}\left(14^{\text {th }}\right.$ of June 2002). The pots were daily watered and weighted at 02.00 p.m.

Leaf area of each plant was measured not-destructively: length $(\mathrm{Lg})$ and width $(\mathrm{Wd})$ of every leaf was converted to leaf area $(y)$ with a previously obtained calibration function $(y=0.6742 x$ $+0.0144, R^{2}=0.98$, where $x=\mathrm{Lg} \cdot \mathrm{Wd}$ ). The calibration equation was obtained by measuring the length the width and the area of 30 leaves of 'Rebula' thus calculating the relationship. The plants were finally destroyed and leaf area measured with leaf area meter Li-Cor 3100 
(Li-Cor Inc., Lincoln, NE, USA). Furthermore they were separated into roots, shoots and leaves and dried in a stove $\left(100^{\circ} \mathrm{C}\right.$ overnight), recording fresh and dry weights.

Stem water potential (Choné et al. 2001) was measured by a Scholander pressure chamber (P.M.S., Corvallis, OR, USA). One leaf for each plant was sampled for each thesis.

Meteorological data: temperature and solar radiation were obtained from the meteorological station of the Experimental farm "Antonio Servadei" of the University of Udine.

Statistical analysis: ANOVA together with Student-Newmann-Keuls test $(P<0,05)$ were used to ascertain differences among means (CoStat, CoHort software, Monterey, CA, USA).

\section{RESULTS AND DISCUSSION}

\section{Leaf area}

At the beginning of the growth period $\left(20^{\text {th }}\right.$ of May 2002) leaf area ranged between $0.009 \mathrm{~m}^{2}$ for plants grafted on 'Rebula' and $0.013 \mathrm{~m}^{2}$ for plants on '196/17 Castel'; in the following period leaf area showed a rapid increase. On $29^{\text {th }}$ June 2002, values about $0.24 \mathrm{~m}^{2}$ were measured and leaf area development showed a decrease of growth rate.

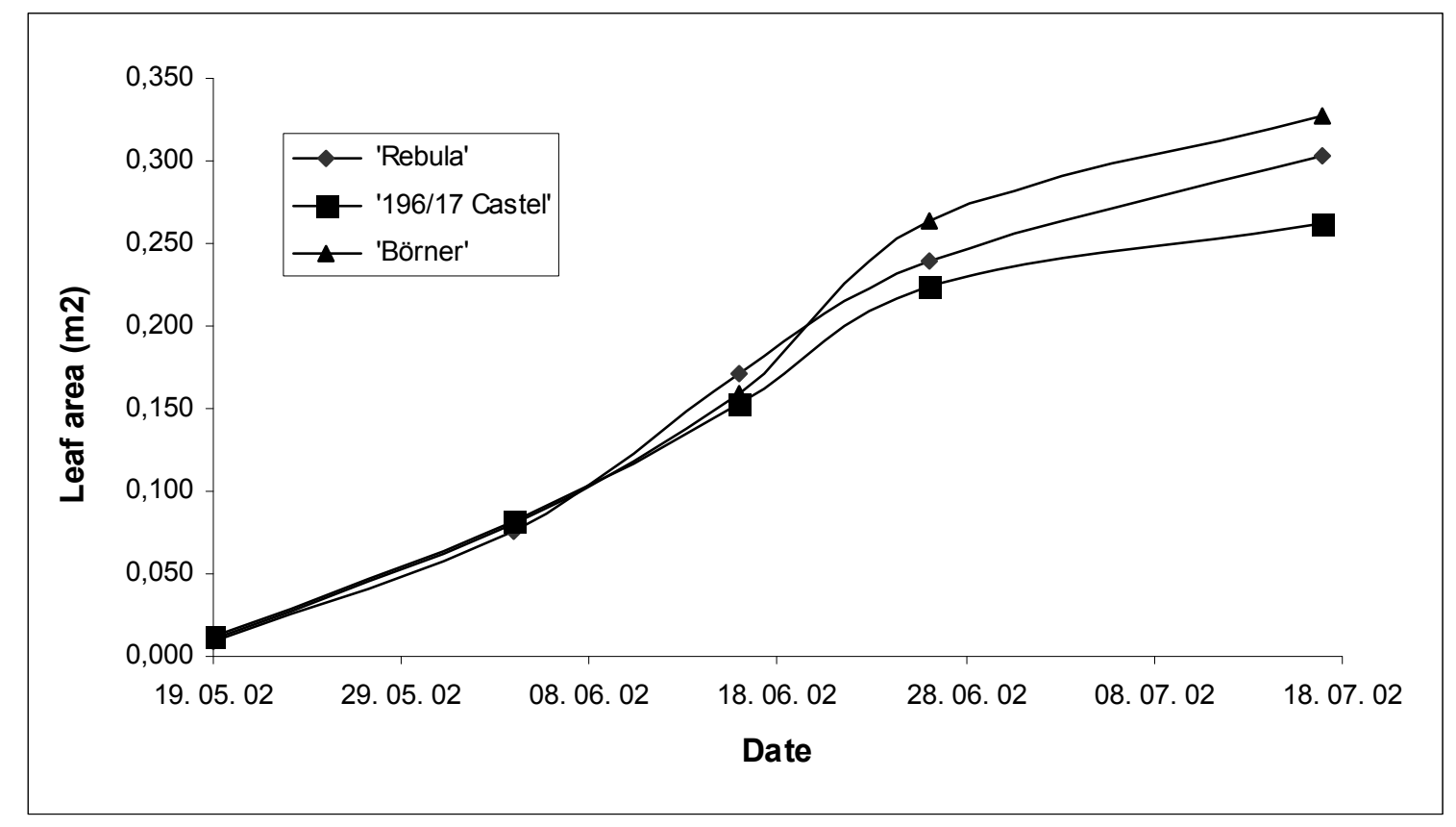

Figure 1. The leaf area of 'Rebula' grafted on three different rootsocks in different dates.

\section{Transpiration}

$\mathrm{T}_{\mathrm{a}}$ data on $11^{\text {th }}$ of June 2002 ranged between $2.24 \mathrm{~L} \mathrm{~m}^{-2}$ leaf area $\mathrm{d}^{-1}$ in 'Börner' and $2.65 \mathrm{~L} \mathrm{~m}^{-2}$ leaf area $\mathrm{d}^{-1}$ in 'Rebula'. From this moment on, $\mathrm{T}_{\mathrm{a}}$ showed a decrease (figure 2), and no difference among rootstocks was observed. Some reductions of $T_{a}$ according with meteorological changes, i.e. a decrease in temperature and radiation were observed (figure 2) particularly on $27^{\text {th }}$ of June and $01^{\text {st }}$ of July 2002. During 
June and July the water consumption of a grafted grapevine with a leaf area of about $0.30 \mathrm{~m}^{2}$ was quite constant with an average from 0.25 to $0.30 \mathrm{~L} \mathrm{H}_{2} \mathrm{O} \mathrm{d}^{-1}$ per plant.

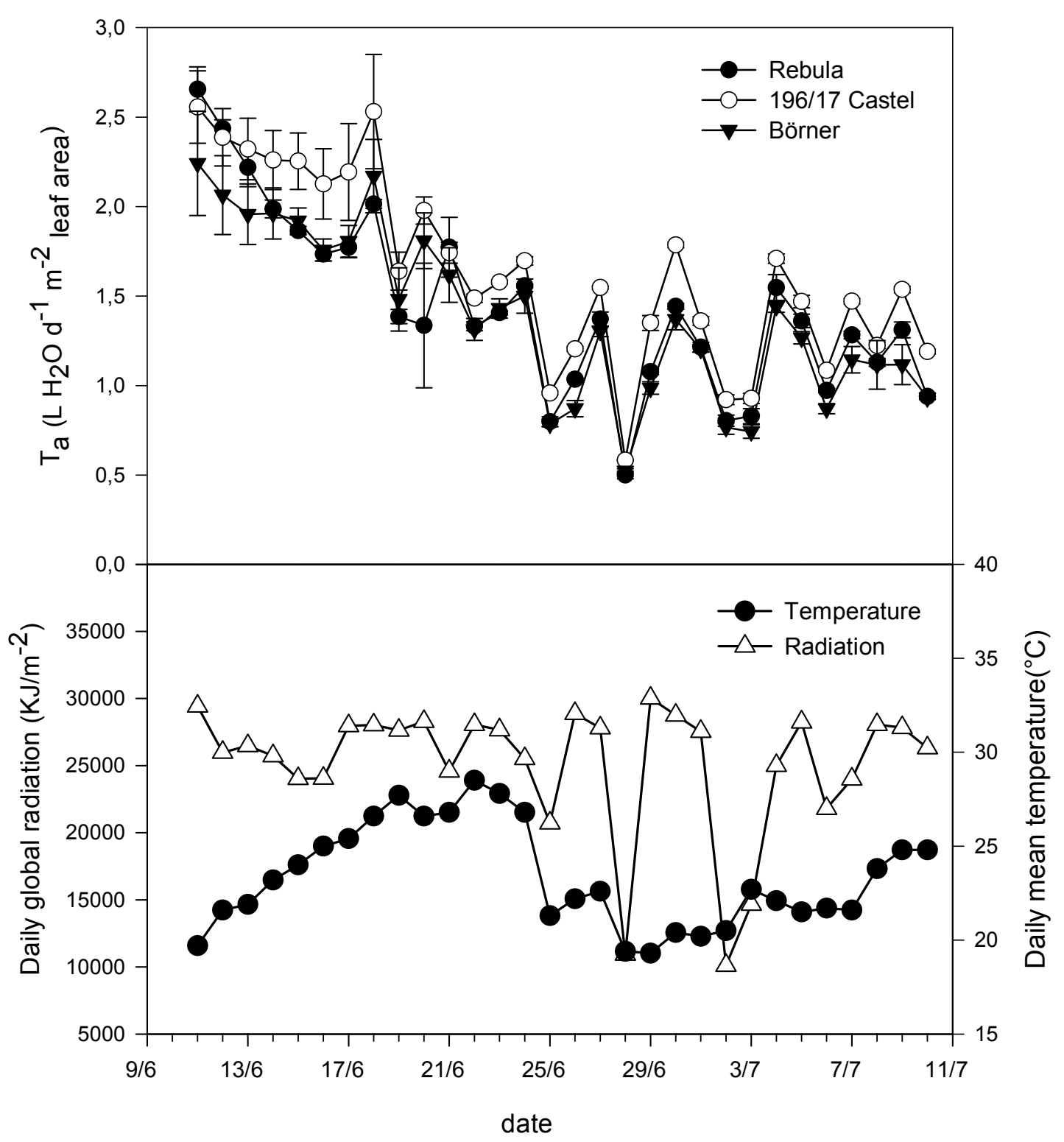

Figure 2. Young grapevine grafted cutting transpiration as affected by rootstock and meteorological changes.

\section{Stem water potential}

On $14^{\text {th }}$ of June stem water potential was measured: plants on 'Rebula' showed a value of -0.53 MPa, while on '196/17 Castel' and 'Börner' -0.54 MPa without significant differences. Stem water potential revealed no water stress in the plants.

\section{Dry matter partitioning}

Dry matter partitioning revealed that 'Börner' rootstock reported the highest values of total leaf area, and the lowest value of root weight. On the opposite, '196/17 Castel' 
rootstock reported the lowest values of leaf area, together with a high root weight. 'Rebula' showed mean values of all dry matter partitioning. Leaf weight did not show any difference, as well as dry matter data.

Table1: Dry matter partitioning of grapevine cuttings grafted on different rootstocks.

\begin{tabular}{|l|l|l|l|l|}
\hline Rootstock & leaf area $\left(\mathrm{cm}^{2}\right)$ & leaf weight $(\mathrm{g} \mathrm{FW})$ & root weight $(\mathrm{g} \mathrm{FW})$ & root/shoot ratio \\
\hline 'Rebula' & $3023.3 \mathrm{ab}^{\mathrm{a}}$ & $47.4 \mathrm{a}$ & $82.1 \mathrm{a}$ & $0.93 \mathrm{a}$ \\
\hline '196/17 Cl' & $2617.5 \mathrm{~b}$ & $43.6 \mathrm{a}$ & $81.8 \mathrm{a}$ & $1.03 \mathrm{a}$ \\
\hline 'Börner' & $3266.1 \mathrm{a}$ & $51.2 \mathrm{a}$ & $59.3 \mathrm{~b}$ & $0.62 \mathrm{~b}$ \\
\hline
\end{tabular}

${ }^{\mathrm{a}}$ values with the same letter are not significantly different for $\mathrm{P} \leq 0.05$.

\section{CONCLUSIONS}

The amount of transpiration was found in agreement with Trambouze and Woltz, 2001 and with Williams et al., 2003 and no differences between rootstocks were assessed. The water consumption data of young grafted grapevines may be useful for irrigation scheduling in nurseries.

\section{ACKNOWLEDGMENT}

This paper was supported by a research grant of the Italian Government, Ministry of Foreign affairs, and by a research grant of Alpe Adria organisation.

\section{REFERENCES}

Choné, X., van Leeuwen, C., Dubourdieu, D., Gaudillère, J. P.. 2001. Stem water potential is a sensitive indicator of grapevine water status. Ann. Bot. 87: 477-483.

Gómez-del-Campo, M., Ruiz, M., Sotés, V., Lissarrague, J.R. 1997. Water consumption, leaf area development and production in four grapevine varieties. Cited in: B. A. Bravdo (Ed.): Proc. $5^{\text {th }}$ International Symposium on Grapevine Physiology: pp. 193-200. Jerusalem, Israel.

Myburgh, P. A., van Zyl, J. L., Conradie, W. J. 1996. Effect of soil depth on growth and water consumption of young Vitis vinifera L. cv. 'Pinot noir'. S. Afr. J. Enol. Vitic. 17(2): 53-62.

Padget-Johnson, M., Williams, L. E., Walker, M.A. 2000. The influence of Vitis riparia rootstock on water relations and gas exchange of Vitis vinifera cv. 'Carignane' scion under non-irrigated conditions. Amer. J. Enol. Vitic. 51(2): 137-143.

Sivilotti, P., Bonetto, C., Paladin, M., Peterlunger, E. 2005. Effect of soil moisture availability on Vitis vinifera cv. 'Merlot': from leaf water potential to grape composition. Amer. J. Enol. Vitic. 56(1): 9-18.

Trambouze, W., Woltz, M. 2001. Measurement and modelling of the transpiration of a Mediterranean vineyard. Agric. For. Meteorol. 107: 153-166.

Williams, L. E., Phene, C. J., Grimes, D. W., Trout, T. J. 2003. Water use of young 'Thompson Seedless' grapevines in California. Irrig. Sci. 22(1): 1-9. 